\title{
Role of the cultural values as a key part in the implementing of healthy practices: An explorative study
}

\author{
Merlin Patricia Grueso, Universidad del Rosario, Cundinamarca, Colombia \\ Claudia Fabiola Rey, Universidad del Rosario, Cundinamarca, Colombia \\ Javier Leonardo González, Universidad del Rosario, Cundinamarca, Colombia
}

\begin{abstract}
The healthy organization concept becomes strong in the corporative and academic environments, due to its integral focus and to the impact it has caused in different interest groups. Due to its recent consolidation as a valid concept, there is little to no corpus of investigation about this topic. In order to generate knowledge focused in this concept, an explorative research which aimed to identify the relationship between implementing healthy organizational practices inside organizations and values was developed. To the research, 66 people were given a questionnaire composed of nine variables, five of them based in the Hofstede model (1980) and four more that evaluated the implementation of healthy organizational practices. The result shows that cultural values predict the implementation of healthy practices at the organization.
\end{abstract}

Keywords: Positive Organizational Studies, Healthy Organizational Practices, Cultural Values, Hofstede's Mode

\section{Introduction}

Corporate culture is a topic which arises a high strategic interest, different studies have shown its predictive capability about the attainment of operative and psychosocial outcomes. Thus, for example, there's evidence of the corporative culture as an accurate predictor of attitudes such as compromise of each member to the corporation (Baumanis, 2002; Cohen, 2000; Geiger, 1998; Lok y Crawford, 2001) and personal satisfaction with the job (Pothukuchi et al, 2002; Silverthorne, 2004); Similarly, it has been well demonstrated that corporative culture presents a high level of statistic affiliation with practices on human resources management (Deal y Kennedy, 1982; Harris y Moran, 1987; 
Papalexandris y Panayotopoulou, 2004). Different studies have also expressed that corporative culture acts as an important predictor and forwarder of business success (Rashid, Sambasivan y Johari, 2003), financial performance (Rashid Sambasivan y Johari, 2003; Van der Post, de Coning, Smith, 1998) and the introduction of innovations (Hofstede et al, 1990). Contrasting with the above said, there are limited studies in which evidence about the existence of statistic relationships between corporative culture and the implementation of corporative routines such as healthy practices can be found, hence this research aims to contribute to the corpus of on-topic investigations.

\section{Corporative culture and healthy practices}

Corporative culture is a key factor in business life (Petigrew, 1979; Schein, 1983); It has been proved that it's also a forwarder of corporative effectiveness (Yilmaz y Ergun, 2008), therein, and since it has been recognized as a key strategic element, the development of studies on corporative culture has grown in a constant basis. As an outcome of the above mentioned, explanatory models have been developed according with the Deal and Kennedy's Cultural Model (1982), the Schein's Dynamic Model of Culture (1984), the Deninson and Mishra's Theoretical Model of Culture Traits (1995) and the Competing Values Framework from Cameron and Quinn (1999). Equally, a wide variety of scales of the culture, such as Norm Diagnostic Index (Allen y Dyer, 1980), Culture Gap Survey CGS (Kilman y Saxton, 1983), Organizational Culture Inventory (Cook y Lafferti, 1986) and Organizational Culture Profile OCP (Broadfoot y Ashkanasy, 1994) have been developed and oriented to an accurate measurement of behavioral patterns.

\section{Corporate Values}

Corporate Values, along with rites, myths and heroes, form the corporative culture (Schein, 1985). Corporative culture is a body of socially distributed cognitive representations about the aims and requirements of a business (Diskienė, Goštautas, 2010). The values of corporative culture are defined as "broad preferences for one state of affairs over others" (Hofstede, 1985, p. 347). 
Being strong predictors of employees' behaviours, the values of the culture have been broadly studied in a corporative context; therefore, some scales have been developed to allow an accurate measurement of such values. The Six Dimensional Model of Organizational Culture (Hofstede et al., 1990), Organizational Culture Assessment (Reigle, 2001), Corporate Culture Survey (Glasser, 1983), Organizational Culture Profile (O’Reilly, Chatman and Caldwell, 1991) and Organizational Value Congruence Scale (Enz, 1986), show the scales used in the study and measurement of cultural values inside organizations.

There's a tradition around the study of the values in corporative cultura in the development of cross cultural studies. Among the most renowned works about such cross cultural studies one can find Trompenaars (1985) and Hofstede (1980). According with Trompenaars' proposal, values inside corporations are expressed amidst seven dimensions: universalism Vs. Particularism, achievement Vs. ascription, individualism Vs. Collectivism, affectivity Vs. neutrality, specific Vs. diffuse, internal control Vs. external control and sequential culture Vs.synchronic culture. Although Trompenaars' proposal has been broadly used in the field of Consultancy (Aciniega, 2001), there is few empiric evidence about its use in the academic field.

Among the cross cultural studies about corporative cultural values, the study proposed by Hofstede, carried on in diffeerent regions and countries around the world, is broadly renowned. Through his investigation, Hofstede identified a set of dimensions which represent the values shared by different societies and that constitute as the basis of the Four Dimensional Model of National Culture Differences. The dimensions initially identified by Hofstede were such as: power distance, masculinity-feminity, individualism-collectivism and uncertainty avoidance. Subsequently, Hofstede and Bond incorporated a fifth dimension to the model, they named this dimension as "Confucian dynamism".

Based on the Four Dimensional Model of National Culture Differences, Hofstede identified some of the inner properties of the mentioned values inside different organizations, thereby 
Hofstede has pointed that the corporations with a long powe distance often present centralized processes, decision-making included. Likewise, Hofstede poses that corporations presenting feminist-oriented values, are marked for the pursuit of parity, solidarity as well as for the quest for a better quality of life. Positive attitudes towards diversity, good level of tolerance, inclusion of minorities and respect for peoples' rights, are all those inner features of corporations with low uncertainty avoidance (Hofstede, 1994). Equally, to this author, inside organizations where collective values prevail, corporate interest is also prevalent. Lastly, and depending on cultural values, Hofstede poses that inside organizations where long term direction prevails as a value; traditions tend to adapt to the context and persevere in the face of slow outcomes in contrast with corporate cultures where short-term direction is prevalent

In spite of the different critics Hofstede's Model (1980) has received (McSweeney, 2002; Signorini, Wiesemes, Murphy, 2009), it has to be admitted that it is a model successfully used in empiric and concept research (Yates and Cutler, 1996). The dimensions contemplated in the Four Dimensional Hofstede's Model (1980), even alone or as the whole model, have served as a base for the setting-up of measurement instruments used in some cross cultural studies. For example, for the Global Research Program GLOBE'S, House et al. (1999) developed a scale of ten dimensions of social and corporative culture, four of such dimensions were taken from Hofstede's model, aiming to validate the existence of relationships between leadership and cultural values in about 150 countries.

Based on the model of cultural values posed by Hofstede, other cross cultural studies have been developed to analize its predictive powers with certain attributes of the corporative culture (Aycan et al, 2000) and in the setting of human resources management practices (Papalexandris y Panayotopoulou, 2004). Hofstede's model has also been used in corporative studies to analize the relationship between cultural values and the development of attitudes towards job such as commitment to the organization (Baumanis, 2002), the adoption of corporate practices (Omar y Urteaga, 2010), corporative sensibility in terms of treatment fairness (Wheeler, 2002), and the professional success of women inside the corporations. 


\section{Healthy practices}

Healthy practices constitute as a relatively new construct, directly derived of the concept of healthy organization. During the last decade a notorious interest about the advance of the consolidation of a concept and research body about the idea of healthy organization has arised, particularly from the positive organizational studies (Goldman, 2004). In this context, healthy corporations are understood as such ones that develop such a structure, a culture, and processes that allow them for high performance levels (McHugh, Humphreys \& McIvor, 2003). Following the same line, Salanova (2008) poses that healthy organizations do define and implement ways and practices in corporative level to promote employees' welfare and consequently, such organizations create high performance products and services, supporting proper relations with in the whole corporative environment as well as with the community.

Two wide variants can be identified within the study of healthy organizations: the first of them aims to the development of explanatory models focused on the employee, as seen in Kelloway \& Day (2005) the heuristic model of healthy organizations, Salanova (2008), and the model posed by Wilson et al. (2004). Complementary, a second slope about healthy organizations can be identified with the development of different models focused on various target groups, such models are: the Modelo Iberoamericano de Excelencia en la Gestión (Fundibeq, 2005) and the EFQM Excellence Model of the European Foundation Quality Management EFQM (s.f), as well as national models such as the Canadian Business Framework for Excellence (NQI, 2007) and the Baldridge National Quality Program (National Institute of Standards and Technology NIST, 1987). These models aim to promote health inside the whole organization by incorporating corporative practices aimed to improve employees', customers', and shareholders' welfare (Corbett, 2004) and its effectiveness (Lim \& Murphy, 1998).

It has been posed through many conceptual approachings over healthy organizations that such organizations do implement practices aimed to achieve a healthy workforce, healthy 
environments as well as healthy finances (Zwetsloot y Pot, 2004). Consequently, this kind

of organizations do emphasize about the quality issue on their products and services, they also give proper response to their clients and customers while keeping a good costeffectiveness ratio; such organizations also make good efforts towards innovations, they also have good communication policies and promote teamwork (Dive, 2004).

It has been pointed about the concept of healthy organizations that corporative culture is a key factor to its consolidation (Kelloway \& Day, 2005; Salanova, 2008; Wilson et al, 2004), however, there's limited thumb evidence about the above mentioned relationship. There is not enough thumb evidence either, about the relationship that can be observed between the values of corporative culture and the adoption of healthy practices by different organizations. Our deep concerns about this lack of evidence on the subject have led to the present research.

\section{Hipotheses}

The Four Dimensional Model of National Culture Differences posed by Hofstede (1980) constitutes as an useful reference point to study inter and intra-organizational phenomena (Doney, Cannon, Mullen, 1998). Such assertion has been demonstrated in cross cultural studies (Aycan et al, 2000; House et al, 1999; Papalexandris \& Panayotopoulou, 2004) as well as in organizational studies (Badjo \& Dickson, 2001; Baumanis, 2002; Omar \& Urteaga, 2010; Wheeler, 2002). The results given by such studies clarify the fact that the cultural values analized under the model posed by Hofstede are powerful predictors of the development of attitudes towards the organization as well as of the adoption of policies aimed towards the workforce and also the adoption of certain cultural practices inside the organizations. On the other hand, it has been clearly demonstrated that the values of the organizational culture determine procedural and operative aspects of the organizations (Kopelman, Brief \& Guzzo, 1990; Schein, 1985; Yilmaz \& Ergun, 2008) and that success on the implementing of management practices depends on such values Macy, 1995). It has also been proven that organizational culture plays a relevant role in the creation and support 
of healthy working environments (Shirey, 2009), the following hipoteses were made based on the above mentioned statements:

H1: The dimensions of power distance, masculinity-feminity, collectivism-individualism, tolerance for uncertainty and short term-long term are variables that predict the adoption of healthy practices related with the development plan inside the organizations in a significant way.

H2: The dimensions of power distance, masculinity-feminity, collectivism-individualism, tolerance for uncertainty and short term-long term are variables that predict the adoption of healthy practices related to the workforce in the organizations in a significant way

H3: The dimensions of power distance, masculinity-feminity, collectivism-individualism, tolerance for uncertainty and short term-long term are variables that predict the adoption of healthy practices related with the external/internal environment in the organizations in a significant way.

H4: the dimensions of power distance, masculinity-feminity, collectivism-individualism, tolerance for uncertainty and short term-long term are variables that predict the adoption of healthy practices related to suppliers and customers in the organizations in a significant way.

\section{Approach}

This research is a non-experimental, transectional study.

\subsection{Variables}

Independent: this ones were built based on the Four Dimensional Model of National Culture Differences, Hofstede (1980) as well as on the dimensión named Confucian Dynamism (Hofstede y Bond, 1988) and were known as: Power distance, masculinity- 
feminity, individualism-collectivism, tolerance for uncertainty, short term-long term orientation.

Dependent: A set of four healthy practices were constituted as variables depending on the study and were known as: Development plan, workforce, concern over internal/external environment, and Suppliers \& buyers.

\subsection{Participants}

The population of the study was narrowed to 350 individuals; all of them were postgraduate students from a management school in Bogotá (Colombia). The estimated sample for the study was narrowed to 184 individuals with a margin of failure of $5 \%$ and a level of trust set at a 95\%, notwithstanding, only 66 individuals gave response, this matches $36 \%$ of the sample. $32 \%$ of the token individuals were male while the $68 \%$ of them were female. The token individuals were between 23 and 51 years of age at the moment of the study and the average was set at 32 years of age.

The surveyed individuals were enrolled to different organizations by the time this study was carried on. $3 \%$ of the polled individuals worked in commerce related businesses, $6 \%$ worked in any kind of factory and the $83 \%$ worked in customer services related businesses As for the size of the organizations, the study showed that $3 \%$ of the polled individuals work in microenterprises, another $3 \%$ does it in small businesses, $14 \%$ work in medium size businesses and the $69,7 \%$ does it in big companies. $11 \%$ of the polled individulas didn't report the size of the businesses they were enrolled to.

\subsection{Tools}

A questionary divided in three paragraphs was designed for this study. The first paragraph aims to gather information on socio-demographical variables of the participants in this study, such variables were: age, gender, studies and type of company they work for. 
The second paragraph of the mentioned questionary contents a set of 35 items related to five cultural values perceived by the polled individulas inside the corporations they work for (Grueso, 2005), such items were based on the Four Dimensional Model of National Culture Differences, (Hofstede, 1980) and on the Confucian Dynamism (Hofstede y Bond, 1988). The dimensions considered for the study as corporative values are:

a. Power distance: The extent the company seeks for decentralization, fairness and participation to. Higher scores, lower power distance.

b. Masculinity-feminity: it measures the way a company fosters democratic decisionmaking processes. Higher scores, more feminity.

c. Individualism-collectivism: the extent to which a company improves different mechanisms to make corporative interests prevail over individual interests. Higher scores, more collective-oriented policies.

d. Tolerance for uncertainty: the extent a company values diversity and respect human rights to. Higher scores, more tolerance for uncertainty.

e. Short term-long term orientation: extent to which a company set mechanisms that allow it to project itself throughout time. Higher scores, more long term orientation.

The last paragraph of the questionary values throughout 17 items the idea the participants have about the adoption of four healthy practices inside the companies they work for. Since the available measures focused in rating of employee oriented practices, a scale rating the level of adoption of healthy practices aimed to different interest groups (workforce, society, suppliers and customers) was built:

a. Development plan: the extent to which a company plans, improves and control actions towards the development of the business. Higher score, healthier practice.

b. Employees: extent to which the company consider physical and mental aspects as well as personal development, communication and participation of the workforce. Hogher score means healthier practice.

c. Care for the internal/external environment: the extent to which a business takes good care of the space in which its activities take place offering a safe and healthy context to its employees as well as good care for the external environment. Higher score, healthier practice. 
d. Suppliers \& customers: the extent to which a company values and sets proper relationships with its suppliers and customers. Higher scores mean a healthier practice.

For assessing the scales related to cultural values and healthy practices a Likert type scale with five answer anchorages was used, being 1 (totally disagree) the lowest one and 5 (totally agree) the highest of such anchorages.

\section{Results}

In order to identify the inner consistency of the scales, the Cronbach's Reliability Coefficient was calculated on them. The outcomes show that such coefficient lies between rational limits since it oscilates between 0,94 (collectivism-individualism) and 0,85 (Short term- Long term Orientation). The four scales concerning healthy practices got reliability coefficients of 0,90. According to Nunnally (1978), coefficients over 0,70 are to be considered as suitable. (Graph 1)

Table I: Cronbach's Reliability Coefficient

\begin{tabular}{|lcc|}
\hline \multicolumn{1}{|c}{ Scale } & N. ítems & $\boldsymbol{\alpha}$ \\
\hline \multicolumn{1}{|c|}{ Cultural Values (Dimensions) } & 7 & 0.92 \\
Power Distance & 7 & 0.88 \\
Masculinity- Femininity & 8 & 0.94 \\
Collectivism - Individualism & 8 & 0.88 \\
Tolerance for Uncertainty & 5 & 0.85 \\
Short Term- Long Term Orientation & & \\
\multicolumn{1}{|c|}{ Healthy Practices } & 3 & 0,90 \\
Development Plan & 5 & 0,90 \\
Employees & 5 & 0,90 \\
Internal and External environment Care & 4 & 0,90 \\
Suppliers and Buyers & & \\
\hline
\end{tabular}

Source: The authors

As it can be observed in Graph II, the dimensions related with cultural values scored between 3,1 and 3,5. About the adoption of healthy practices, it can be noted that the 
practice aiming to a better Development Plan $(3,3)$ got the highest score, in the other hand, the practice dealing with workforce was the less favorably rated $(2,6)$.

Table II. Descriptive Statistics

\begin{tabular}{|l|c|c|c|}
\hline & Mean & $\begin{array}{c}\text { Std. } \\
\text { Deviation }\end{array}$ & $\mathrm{N}$ \\
\hline Cultural Values & 3,1 & 1,00782 & 66 \\
Power distance & 3,3 &, 83905 & 66 \\
Masculinity- Femininity & 3,2 & 1,00527 & 66 \\
Collectivism - Individualism & 3,2 &, 87745 & 66 \\
Tolerance for Uncertainty & 3,5 &, 85723 & 66 \\
Short - Long Term Orientation & & & \\
Healthy Practices & 3,3 &, 96738 & 66 \\
Development Plan & 2,6 &, 96325 & 66 \\
Employees & 2,9 & 1,05707 & 66 \\
Internal and external Environment Care & 3,2 &, 98400 & 66 \\
Suppliers and Buyers & \multicolumn{2}{|r}{} \\
\hline
\end{tabular}

Source: The autors

In order to test the hypotheses posed in this study, a regression ANOVA analysis was carried on through sequencial steps. Based on the coefficients of regression shown by such analysis, it's possible to state that hypotheses 1, 2, 3 and 4 do receive empiric support though in a partial way (Tables 3 to 6 ). In the study it had been posed that dimensions such as power distance, masculiity-feminity, collectivism-individualism, tolerance for uncertainty and short term-long term orientation were cultural values that predicted the adoption of healthy practices related with the development plan of the organization $(\mathrm{H} 1)$.

The results to the study suggest that the short term-long term orientation dimension is the only cultural variable significantly related with the adoption of healthy practices aimed to the development plan $(\mathrm{Sig}=0,000)$. The results do not evidence statistically meaningful relationships between power distance, masculinity-feminity, collectivism-individualism and tolerance for uncertainty dimensions and the adoption of practices related with the development plan. (Table III). 
Table III. Regression Coefficients Cultural values vs Development Plan

\begin{tabular}{|l|c|c|c|c|c|}
\hline \multirow{2}{*}{ Model } & \multicolumn{2}{|c|}{$\begin{array}{c}\text { Unstandardized } \\
\text { Coefficients }\end{array}$} & $\begin{array}{c}\text { Standardized } \\
\text { Coefficients }\end{array}$ & & \\
\cline { 2 - 5 } & $\mathrm{B}$ & $\begin{array}{c}\text { Std. } \\
\text { Error }\end{array}$ & Beta & t & Sig. \\
\hline (Constant) &, 997 &, 416 & & 2,398 &, 019 \\
Short-Long Term &, 666 &, 114 &, 591 & 5,854 &, $000^{*}$ \\
\hline
\end{tabular}

$* \mathrm{p}<=0,05$ Source: The autors

It had been posed in the reasearch that dimensions such as power distance, masculinityfeminity, collectivism-individualism, tolerance for uncertainty and short term-long term orientation considered as cultural values were also predicting variables about the adoption of healthy practices related to employees $(\mathrm{H} 2)$. The results show that the power distance dimension is the only cultural variable significantly related with the practices oriented to the employees $(\mathrm{Sig}=0,000)$. Such statistic relationship is not evidenced in relation with the masculinity-feminity, collectivism-individualism, tolerance for uncertainty and short termlong term orientation dimensions (Table IV).

Table IV. Regression Coefficients Cultural Values vs Employees

\begin{tabular}{|l|c|c|c|c|c|}
\hline \multirow{2}{*}{ Model } & \multicolumn{2}{|c|}{$\begin{array}{c}\text { Unstandardized } \\
\text { Coefficients }\end{array}$} & $\begin{array}{c}\text { Standardized } \\
\text { Coefficients }\end{array}$ & & \\
\cline { 2 - 5 } & $\mathrm{B}$ & $\begin{array}{c}\text { Std. } \\
\text { Error }\end{array}$ & Beta & $\mathrm{t}$ & Sig. \\
\hline (Constant) &, 283 &, 234 & & 1,209 &, 231 \\
Power Distance &, 766 &, 071 &, 802 & 10,740 &, $000 *$ \\
\hline
\end{tabular}

$* \mathrm{p}<=0,05$ Source: The autors

Similarly, it had been posed as an hypothesis to the study that the dimensions known as power distance, masculinity-feminity, collectivism-individualism, tolerance for uncertainty and short term-long term orientation were powerful predicting variables of the adoption of healthy practices related with concerns about the external/internal environment $(\mathrm{H} 3)$. The 
results evidence that the collectivism-individualism dimension predicts the adoption of healthy practices aimed to take good care of the external and internal environments ( $\mathrm{Sig}=$ 0,000 ) in a significant way. In the other hand, the dimensions such as power distance, masculinity-feminity, tolerance for uncertainty and short term-long term orientation do not have predictive power in the adoption of healthy practices concerned with the care for the external/internal environment (Table V)

Table V. Regression Coefficients Cultural values vs Internal and External Environment

\begin{tabular}{|l|c|c|c|c|c|}
\hline \multirow{2}{*}{ Model } & \multicolumn{2}{|c|}{$\begin{array}{c}\text { Unstandardized } \\
\text { Coefficients }\end{array}$} & $\begin{array}{c}\text { Standardized } \\
\text { Coefficients }\end{array}$ & & \\
\cline { 2 - 5 } & $\mathrm{B}$ & $\begin{array}{c}\text { Std. } \\
\text { Error }\end{array}$ & Beta & t & Sig. \\
\hline (Constant) &, 889 &, 355 & & 2,507 &, 015 \\
Collectivism- &, 640 &, 104 &, 609 & 6,141 &, $000 *$ \\
Individualism & & & & & \\
\hline
\end{tabular}

$* \mathrm{p}<=0,05$ Source: The authors

Finally, it had been hypothesized that such cultural dimensions as power distance, masculinity-feminity, collectivism-individualism, tolerance for uncertainty and short termlong term orientation were predicting variables of the adoption of healthy practices related with suppliers'-customers'-company relationships (H4)

The results show that the variable known as short term-long term orientation is the only one that predicts the adoption of healthy practices aimed to suppliers and customers (Sig: 0,000) in a significant way. The remaining dimensions incorporated within the study do not seem to be predictors of healthy practices aimed to suppliers and customers (Table VI).

Table VI. Regression Coefficients Cultural values vs Suppliers and Buyers

\begin{tabular}{|l|c|c|c|c|c|}
\hline \multirow{2}{*}{ Model } & \multicolumn{2}{|c|}{$\begin{array}{c}\text { Unstandardized } \\
\text { Coefficients }\end{array}$} & $\begin{array}{c}\text { Standardized } \\
\text { Coefficients }\end{array}$ & & \\
\cline { 2 - 5 } & $\mathrm{B}$ & $\begin{array}{c}\text { Std. } \\
\text { Error }\end{array}$ & Beta & $\mathrm{t}$ & Sig. \\
\hline $\begin{array}{l}\text { (Constant) } \\
\begin{array}{l}\text { Short-Long Term } \\
\text { Orientation }\end{array}\end{array}$ &, 942 &, 432 & & 2,179 &, 033 \\
\end{tabular}

$* \mathrm{p}<=0,05$ Source: The autors 
Table VII summarizes the results collected with the regression analysis. Specifically, three of the five mentioned dimensions incorporated within the study, evidence some predictive power about the adoption of healthy practices.

Table VII. Relationships between Cultural Values and Healthy Practices

\begin{tabular}{|l|c|c|c|c|}
\hline $\begin{array}{c}\text { Cultural Values vs Healthy } \\
\text { Practices }\end{array}$ & $\begin{array}{l}\text { Internal and } \\
\text { External } \\
\text { Environmental } \\
\text { Care }\end{array}$ & $\begin{array}{l}\text { Suppliers } \\
\text { and Buyers }\end{array}$ \\
\hline Power distance & $*$ N.R. & S.R. & N.R. & N.R. \\
\hline Masculinity- Femininity & N.R. & N.R. & N.R. & N.R. \\
\hline Collectivism - Individualism & N.R. & N.R. & S.R. & N.R. \\
\hline Tolerance for Uncertainty & N.R. & N.R. & N.R. & N.R. \\
\hline Short - Long Term Orientation & $* *$ S.R. & N.R. & N.R. & S.R. \\
\hline
\end{tabular}

*N.R: No relationships. ${ }^{* *}$ Significant Relationships

Source: The authors

\section{Conclusions}

This research was thought as of an exploratory nature in order to analyze the predictive power of the corporative values over the adoption of healthy practices using Hofstede's Four Dimensional Model of Culture as a base reference as well as Confucian Dinamism (Hofstede \& Bond (1989). The results give partial support to the hypotheses posed along the corpus of this research. three of the five dimensions observed in this research present some predictive power over the adoption of healthy practices but in different ways; thereby, the dimension known as power distance is only seen as related with workforce related healthy practices. According to Hofstede, power distance expresses relationships such as subordination and authority; among the healthy practices within the study, just the one related with workforce could be considered as the object of such relationships in a direct and significant way.

Equally, the results of the study have evidenced that the dimension known as collectivismindividualism predicts the adoption of healthy practices oriented to care for the external/internal environment in a significant way. As it has been pointed by Hofstede, 
(1994), organizations with collective values focus on aspects such as physical conditions of work environment, this allows for the assumption about the existence of statistically significant relationships between this value and the adoption of healthy practices concerned with the care for the internal/external environment and, consequently, evidences it empirically. Notwithstanding, it has been pointed that organizations with collective values also focus on their workforce's development of habilities (Hofstede, 1994), such association was not evidenced in relationship with the adoption of workforce oriented healthy practices. Another notorious attribute of organizations with collective values seems to be the setting of moral relationships (Hofstede, 1994), it was expected to prove the exsistence of any statistically significant relationship between the mentioned dimension and healty practices aimed to suppliers and customers, in spite of this, shuch relationships could not be evidenced within the study.

Equally, the research leads to the conclusion that there are statistically significant relationships between the dimension known as short term-long term orientation as a cultural value and the adoption of healthy practices oriented towards the Development Plan and to suppliers and customers. According to Hofstede \& Bond (1988), long term oriented organizations use to show respect for the social context they live in; it's explainable then that such type of organizations are willing to adopt healthy practices in order to sustain proper relationships with other participants such as suppliers and customers, that's to say, that they adopt an approach as stakeholders. Complementarily, Hofstede \& Bond (1988) point that long term oriented organizations are persistent; by implementing actions aimed to orient and control the future of the organization throughout the Development Plan, the organizations considered within the study, are being consistent with such value. What it's not explainable within the research is why short term-long term dimension does not seem to have statistically significant relationships with workforce and environtment care oriented healthy practices.

Though it had been hyothesized within the research that the predictive power of masculinity-feminity and tolerance for uncertainty dimensions over the adoption of healthy practices, the results didn't offer practical support to such statements. It's necessary to 
analyze such results on the light of further studies. On analyzing the six dimensions of corporative culture in terms of national dimensions, Hofstede et al. (1990) identified that only tolerance for uncertainty and power distance were statistically related with some dimensions of corporative culture. Within such study (Hofstede et al, 1990) it was evidenced that masculinity-feminity and collectivism-individualism dimensions did not present statistically significant relationships with any of the dimensions of corporative culture.

As a result of such discoveries, Hofstede notes that corporative culture has a high component of practices in contrast with different national cultures that present a high component of values; thence, studying corporative culture from national culture dimensions it's a partially useful practice.

Contrasting with the discoveries made by Hofstede et al. (1990), on comparing the existence of relationships between national values and corporative practices, among differnt Argentinian businesses (ten state-run and also six private companies) Omar \& Urteaga (2010), found that national culture values constitute as a valid reference for studying the introduction of practices into organizations. In their study, Omar \& Urteaga concluded that the practices implemented by the organizations were strongly associated with culture values from the provenience of said organizations. Given the contrast between the results gathered by Hofstede and by Omar \& Urteaga, it would be valid to analyze the reasons for these differences to appear in detail.

Within previous studies statistically significant relationships had been identified between Hofstede's Four Dimensional Model of National Differences (1980) and certain organizational processes and attitudes towards job and it was stated also that such model constitutes as a valid reference for studying intra-organizational/inter-organizational phenomena (Doney, Cannon, Mullen, 1998). In spite of the before said, the evidence found doesn't allow to uphold such discoveries. More research is needed in order to achieve a better understanding about the best way for operationalizing the set of values of national culture as practices. Another research alternative could be aimed to consolidate a corpus 
about organizational culture values; as Hofstede has pointed out, such values seem to be different from values in other social environments.

The study presents some limitations, i.e. the size of the sample used must be improved. Since it was an exploratory study, it's needed to carry on a research that includes a statistically representative demographic sample that allows for the achievement of conclusions with a lesser error margin. It would be relevant to also study the link of the variables incorporated within the study inside just one organization or among different companies in the same economical niche. It could be also posible to carry on different studies in countries with notorious cultural differences.

Finally, it's needed to keep on studying the impact caused by organizational culture and its values to the adoption of healthy practices since it has been largely demonstrated that success on implementing of management practices depends on business' own values (Macy, 1995). It's also needed to keep on developing measurement scales and conceptual approaches about healthy practices and organizations from the positive organizational studies, whereas literature and practical evidence about the topic is still limited and it's a concept stream that begins to position itself within the academic environment.

\section{Bibliografía}

Allen, F.; Dyer, J. (1980). Norms Diagnostic Index: A Tool for Tapping the Organizational Unconcious. Personnel Journal, 223, 192-198.

Arciniega, L, M. (2001). Desarrollo y validación de un modelo heurístico sobre valores en el trabajo. Tesis de Doctorado para la obtención del Título de Doctor en Psicología Social, Departamento de Psicología Social y Antropología, Universidad de Salamanca, Salamanca, España.

Aycan, Z.; Kanungo, R. ; Mendonca, M. ; Yu, K.; Deller, J. , Stahl, G. ; Kurshid, A. (2000). Impact of Culture on Human Resource Management Practices: A 10- 
Country Comparison. Applied Pscychology: An International Review, 49, (1) 192221.

Badjo, L.; Dickson, M. (2002). Perceptions of Organizational Culture and Women's advancement in Organizations: A Cross-Cultural Examination. Sex Roles, 45, (5/6), 399-414.

Baumanis, L. (2002). Cultural Values and Organizational Commitment among financial consultants in South Florida. Doctoral Dissertation in International Business Management, Wayne Huizenga Graduate School of Business and Entrepreneurship, Nova Southeastern University.

Broadfoot L. E.; Ashkanasy, N. M. (1994). A Survey of Organizational Culture Measurement Instruments. Paper presented at the Annual General Meeting of Australian Social Psychologists, Queensland, Australia.

Cameron, K.; Quinn, R. (1999). Diagnosing and changing organizational culture. New York: Addison Wesley.

Cohen, A. (2000). Does cultural socialization predict multiple bases and foci of commitment. Journal of Management, 26 (1), 5-31.

Cook, R. A.; Lafferty, J. C. (1986). Organizational culture inventory. Plymouth, MI: Human Synergistics.

Corbett, D. (2004). Excellence in Canada: Healthy Organizations - Achieve Results by Acting Responsibly. Journal of Business Ethics, 55, 125-133.

Deal, T. E.; Kennedy, A. A. (1982). Corporate cultures: The rites and rituals of corporate life. Reading: Addison Wesley. 
Denison, D.; Mishra, A. (1995). Toward a Theory of Organizational Culture and Effectiveness. Organization Science, 6 (2),204-223.

Diskienè, D.; Goštautas, V. (2010). Relationship between individual and organizational values and employees' job satisfaction. Current Issues of Business and Law, 5 (2) 295-319.

Dive, B. (2004). Healthy Organization. Kogan Page Ltd.: London.

Doney, P.; Cannon, J.; Mullen, M. (1998). Understanding the influence of National Culture on the development of trust. The Academy of Management Review, 23 (3), 601-620.

Enz, C.A. (1986). New Directions for Cross-Cultural Studies: Organizational Cultures and Societal Heterogeneity. In R. N. Farmer (Ed.), Advances in International Comparative Management (173-190). Greenwich, CT: JAI Press.

Geiger, G. (1998). The impact of cultural values on escalation of commitment. International Journal of Organizational Analysis, 6 (2), 165-177.

Glasser, R. (1983). The Corporate Culture Survey. Organizational Design and Development, Bryn Mawr, PA.

Goldman, K. (2004). The possibility of healthy organizations: Toward a new framework for organization theory and practice. Journal of Applied Sociology/Sociological Practice 21 (2)/ 6 (2), 57-79.

Grueso, M. P. (2005). Cultura Organizacional y prácticas de recursos humanos: Un estudio preliminar desde la perspectiva de género. VI Taller Internacional Mujeres en el Siglo XXI, 431 - 447. 
Harris, P. R.; Moran, R. T. (1987). Managing Cultural Differences, 2nd Edition. Houston: Gulf Publishing Co.

Hofstede, G. (1994). Culture and Organizations: Software of the mind. Intercultural Cooperation and it's importance for survival. London: HarperCollinsBusiness.

Hofstede, G. (1985). The interaction between national and organizational value systems. Journal of Management Studies, 22 (4), 347-357.

Hofstede, G. \& Bond, M. (1988). The Confucius connection: from cultural roots to economic growth. Organizational Dynamics, 16 (4) 4-21.

Hofstede, G.; Neuijen, B.; Ohayv, D.; Sanders, G. (1990). Measuring organizational cultures: A qualitative and quantitative study across twenty cases. Administrative Science Quarterly, 35 (2) 286- 316.

Hofstede, G. (1980). Cultures Consequences: International differences in work related value. Newbury Park, CA.: Sage.

House, R. J., Hanges, P. J., Ruiz-Quintanilla, S. A., Dorfman, P. W., Falkus, S. A. and Ashkanasy, N. M. (1999). Cultural influences on leadership and organizations: Project Globe. In W. H. Mobley, M. J. Gessner and V. Arnold (Ed.), Advances in Global Leadership, 2 Ed. (pp. 171-233) Bingley, UK: Emerald Group Publishing Ltd.

Kelloway, E. K.; Day, A. (2005). Building healthy workplaces: What we know so far. Canadian Journal of Behavioural Science, 37 (4), 223-249.

Kilman, R. H.; Saxton, M. J. (1983). The Kilman-Saxton Culture-Gap Survey. Pittsburgh, PA: Organizational Design Consultants. 
Lok, P. \& Crawford, J. (2001). Antecedents of organizational commitment and the mediating role of job satisfaction. Journal of Managerial Psychology, 16 (8), 594613.

Macy, G. (1995). The role of values in implementing progressive organizational practices. International Journal of Value-Based Management, 8 (1) 39-51.

McSweeney, B. (2002). Hofstede's model of national cultural differences and their consequences: a triumph of faith - a failure of analysis. Human Relations, 55 (1) 89118.

Nunnally, J. (1978). Psychometric Theory. (2 $2^{\text {a }}$ Edition) New York: McGraw Hill.

Omar, A.; Urteaga, A. (2010) El impacto de la cultura nacional sobre la cultura organizacional. Universitas Psychologica, 9 (19), 79-92.

O'Reilly, C.A.; Chatman, J.; Caldwell, D.F. (1991). People and organizational culture: a profile comparison approach to assessing person-organization fit. Academy of Management Journal, 34 (3) 487-516.

Papalexandris, N.; Panayotopoulou, L. (2004). Exploring the mutual interaction of societal culture and human resource management practices: Evidence from 19 countries. Employee Relations, 26 (5) 495-509.

Pettigrew, A. (1979). On studying organizational cultures. Administrative Science Quarterly, 24 (4), 570-581.

Pothokuchi, V.; Damanpour, F.; Choi, J.; Park, S. (2002). National and Organizational Culture differences and International Joint Venture Performance. Journal of International Business Studies, 33 (2), 243- 265. 
Rashid, M. Z., Sambasivan, M., Johari (2003). The influence of corporate culture and organizational commitment on performance. The Journal of Management Development, 22, 7/8, 708-728.

Reigle, R. F. (2001). Measuring organic and mechanistic culture. Engineering Management Journal, 13 (4), 1-8.

Salanova, M. (2008). Organizaciones Saludables: Una aproximación desde la Psicología Positiva. En C. Vásquez y. Hervás, G (Eds) Psicología Positiva: bases científicas del bienestar y la resiliencia (págs. 403-427). Bilbao: Desclée De Brower.

Schein, E. (1983). The role of the founder in the creation of organizational culture. Organizational Dynamics, 12 (1) 13-28.

Schein, E. (1984). Coming to a New Awareness of Organizational Culture. Sloan Management Review, 25 (2), 3-16.

Signorini, P.; Wiesemes, R.; Murphy, R. (2009). Developing alternative frameworks for exploring intercultural learning: a critique of Hofstede's cultural difference model. Teaching in Higher Education, 14 (3) 253-264.

Silverthorne, S. (2004). The impact of organizational culture and person-organization fit on organizational commitment and job satisfaction in Taiwan. The Leadership and Organization Development Journal, 25 (7), 592-599.

Trompenaars, A. M. (1985). The organization of meaning and the meaning of organization: A comparative study on the conceptions of organizational structure in different cultures. Doctoral Tesis, Wharton School of the University of Pennsylvania, Social Systems Department.

Shirey, M. (2009) Authentic Leadership, Organizational Culture, and Healthy Work Environments. Critical Care Nursing Quarterly. 32(3), 189-198. 
Van der Post, W.Z., de Coning, T.J., Smith, E. (1998). The relationship between organizational culture and financial performance. South African Journal of Management, 29 (1) 30-41.

Yates, G.; Cutler, B. (1996). Hofstede's Model of National Culture. Journal of Teaching International Business, 8 (2) 77-93.

Yilmaz, C.; Ergun, E. (2008). Organizational culture and firm effectiveness: An examination of relative effects of culture traits and the balanced culture hypothesis in an emerging economy. Journal of World Business, 43, 290-306.

Wheeler, K. G. (2002). Cultural Values in relation to equity sensitivity within and across cultures. Journal of Managerial Psychology, 17, (7) 612- 627.

Wilson, M.; DeJoy, D.; Vandenberg, R.; Richardson, H.; \& McGrath, A. (2004). Work characteristics and employee health and well-being: Test of a model of healthy work organziation. Journal of Occupational and Organizational Psychology, 77, 565588.

Zwetsloot, G.; Pot, F. (2004). The Business Value of Health Management. Journal of Business Ethic, 55, 115-124 